GEOPHYSICAL RESEARCH LETTERS, VOL. 14, NO. 6, PAGES 611-613, JUNE 1987

\title{
VERTICAL PROFILE OF KRYPTON-85 IN THE STRATOSPHERE
}

\author{
Joseph SANAK, Alain JEGOU and Gérard LAMBERT
}

Centre des Faibles Radioactivités, Laboratoire Mixte CNRS-CEA Avenue de la Terrasse, 91190 Gif-sur-Yvette, France

\begin{abstract}
A vertical profile of Krypton-85 from 12 to $40 \mathrm{~km}$ height was obtained from a balloon-borne experiment. The results display a clear concentration gradient between the troposphere and $22 \mathrm{~km}$. Above this altitude, the concentration varies very little, in agreement with theoretical predictions.
\end{abstract}

\section{Int roduction}

Stratospheric ozone is directly affected by changes in the concentrations of trace gases, which are injected into the lower atmosphere by human activities. The concentrations of these gases result from both atmospheric transport and chemical reactions, in connection with solar rays. The kinetics of these reactions are far from being known with the desirable accuracy. However parametrizations of the vertical transport are generally not introduced in the models as independent data, but are calculated from the distribution of chemical species. Therefore, it should be particularly useful to make use of an independent tracer which is not involved in the whole chemical system. This is precisely the interest of krypton-85 measurements.

Remember that Krypton-85 is injected into the lower troposphere essentially by the reprocessing of nuclear fuels. As a noble gas, it is chemically inert and disappears from the atmosphere only by radioactive decay, with an halflife of 10.76 years. Its concentration has been monitored in the troposphere since 1950 (Weiss et al., 1983; Dvorak and Wilhelmova, 1984). The annual increase is presently of the order of $2.15 \times 10^{-2} \mathrm{~Bq} . \mathrm{kg}^{-1} \mathrm{yr}^{-1}$, i.e. about 3.5 i per year (Weiss et al., 1986). At the end of 1986 it was approximately 0.70 . Bq. kg ${ }^{-1}$ in the troposphere.

Some rare measurements of $\mathrm{kr}-85$ were obtained from time to time in the lower layers of the stratosphere by Pannetier (1968), Telegadas and Ferber (1975), and recently by Weiss and collaborators (unpublished results). However, to our knowledge, no measurement has ever been published at altitudes of 28-40 km, for which vertical transport data are particularly lacking. The aim of this paper is to report one $\mathrm{Kr}-85$ vertical profile in this altitude range.

\section{Sampling and measurements}

A balloon-borne experiment was launched from Aire-sur-I'Adour (France) on November 16th 1986, during a period of very strong winds in the upper stratosphere.

The sampled air was first compressed by a mechanical booster pump, and then by a one stage

Copyright 1987 by the American Geophysical Union.

Paper number 7L6539.

0094-8276/87/007L-6539\$03.00 rotary pump. Oil and water vapours were removed in a liquid nitrogen cooled trap, and the air was blown through one trap filled with activated charcoal, and maintained at $120 \mathrm{~K}$ by liquid nitrogen. The sampling device comprised five such independent traps selected by valves operated by remote control. At the end of the line the air pressure was automatically controlled at a value of about $10^{6} \mathrm{~Pa}$ for which the sampling efficiency is optimal.

After recovering the sampler the air, already enriched in rare gases, was desorbed by heating and the krypton of the air was again trapped in cold charcoal and then separated and measured by gas chromatography. This krypton was subsequently introduced into a beta counter whose volume was completed by a classical ArgonMethane mixture, in order to measure the $\mathrm{Kr}-85$ activity. The background of this counter is 0.55 pulse per minute and its efficiency is 78 . As the krypton mixing ratio of $1.14 \times 10^{-6}$ is constant in air throughout the middle atmosphere, the knowledge of the volume of krypton introduced into the counter gives the amount of air to which the $\mathrm{Kr}-85$ activity must be ascribed.

Four samples were collected during the flight. A fifth trap was maintained closed during the flight as a blank, in order to detect the presence of any contamination.

\section{Discussion and conclusion}

The results of the measurements are shown in Table 1. As a comparison, the values calculated from the vertical transport coefficients proposed by Chang (1976) are also indicated.

The activity of the blank was not detectable. The decay of the $\mathrm{Kr}-85$ concentration versus altitude is very clear above the tropopause situated at $11.58 \mathrm{~km}$ height as well as from 15 to $22 \mathrm{~km}$ (fig.1). The concentration is practically constant between 30 and $40 \mathrm{~km}$, which implies either very rapid vertical mixing at these altitudes as proposed by Chang (1976) and Crutzen et al (1976), or an advection from other parts of the stratosphere in agreement with Telegadas and Ferber (1975) and the theoretical considerations of Holton (1986). However between the tropopause and $22 \mathrm{~km}$ helght, the concentration decrease is significantly more rapid than expected from the ID model proposed by Cariolle (1980).

Because of the small number of experimental results, it is impossible to calculate transfer coefficients, but only an "apparent" age of the air masses, defined as the time span since their entry into the stratosphere. This age varies from 2.3 year in the lower stratosphere to about 8 years in the upper stratosphere. 
TABLE 1. Vertical profile of krypton-85

\begin{tabular}{lcccc}
\hline $\begin{array}{c}\text { Altitude } \\
\text { hPa } \\
(\mathrm{km})\end{array}$ & $\begin{array}{c}\text { Air volume } \\
\text { sampled } \\
\text { TPN litre }\end{array}$ & $\begin{array}{c}\text { Activity } \\
\text { Bq/kg of air } \\
( \pm 16)\end{array}$ & $\begin{array}{c}\text { Apparent } \\
\text { age } \\
(\text { year })\end{array}$ & $\begin{array}{c}\text { Calculated } \\
\text { activity } \\
\text { Bq } / \mathrm{kg} \text { of air }\end{array}$ \\
\hline $\begin{array}{l}186-117 \\
(12.26-15.2)\end{array}$ & 10.0 & $0.60 \pm 0.02$ & 2.3 & 0.65 \\
$38.4-26.2$ & 28.3 & $0.42 \pm 0.01$ & 7.8 & 0.51 \\
$(22.35-24.8)$ & & & & \\
$10.07-6.64$ & 8.4 & $0.40 \pm 0.02$ & 8.6 & 0.47 \\
$(30.75-34)$ & & & 8.8 & 0.46 \\
$3.77-2.84$ & 18.1 & $0.395 \pm 0.005$ & & \\
$(38-40)$ & & & & \\
\hline
\end{tabular}

(*) Values calculated from the vertical transport coefficients proposed by Chang (1976) and from the lower tropospheric Kr-85 concentration since 1950 (Dvorak and Wilhelmova, 1984; Weiss et al., 1986) with the 1D model proposed by Cariolle (1980).

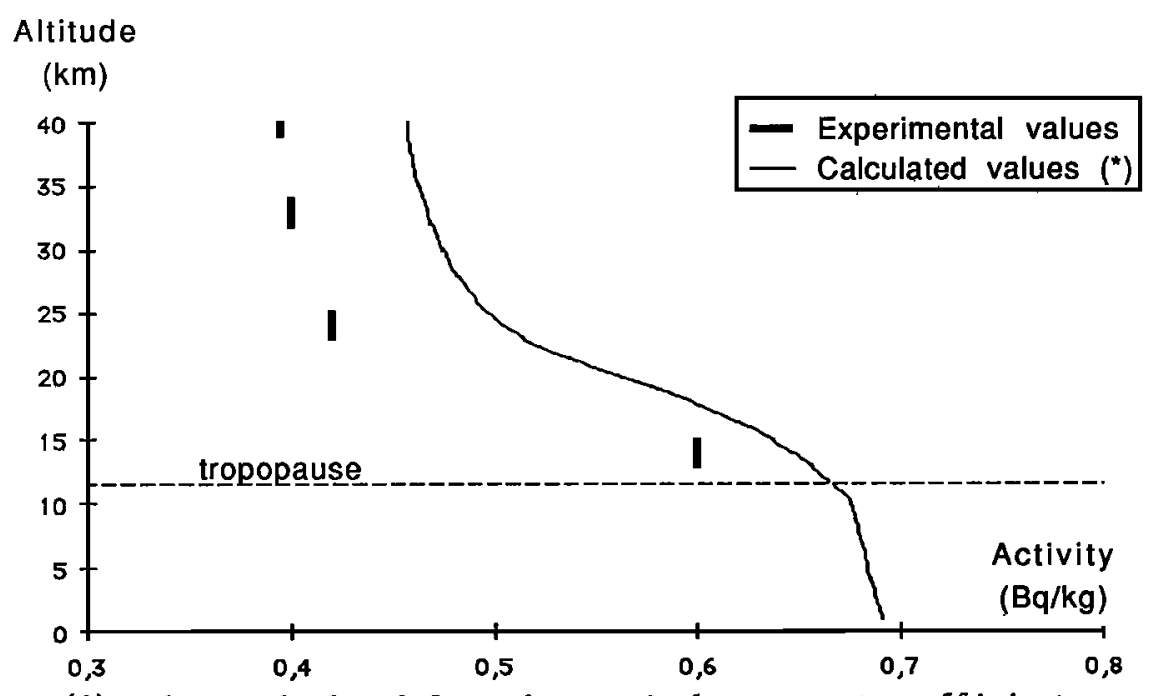

(*) Values calculated from the vertical transport coefficients proposed by Chang (1976) and from the lower tropospheric $\mathrm{Kr}-85$ concentration since 1950 (Dvorak and Wilhelmova, 1984; Weiss et al., 1986) with the 1D mode1 proposed by Cariolle (1980).

Fig. 1. Observed and calculated $\mathrm{Kr}-85$ profiles on November $16 \mathrm{th}, 1986$.

Acknowledgements. This work was supported by the CNRS (ATP atmosphere moyenne), and by the CNES. The authors thank particularly the department "Balloons" of the CNES, as well as D. Cariolle and $w$. Weiss for their useful advice. This is the C.F.R. contribution No 845 .

\section{References}

Dvorak z. and L. Wilhelmova, Krypton-85 v atmosphere : urovne kontaminace $\mathrm{v}$ letech 1950-80, Jaderna Energie, 30, 23-28, 1984.

Cariolle D., Etude de l'impact des activités humaines sur l'ozone stratosphérique à l'aide d'un modèle unidimentionnel photochimique, Note T'echnique E.E.R.M., Météorologie Nationale, $\mathrm{N}^{\circ} 79$ NS, 1980.
Chang J., Halocarbons : effects on stratospheric ozone, US National Acad. Sci., Washington DC, USA, 1976.

Crutzen P.J., I.S.A. Isaksen and R. McAfee, The impact of the chlorocarbon industry on the ozone layer, $J$. Geophys. Res., 83, 345-363, 1978 .

Holton J.R., A dynamically based transport parametrization for one-dimensional photochemical models of the stratosphere, J. Geophys. Res., 9, 2681-2686, 1986 .

Pannetier R., Distribution, transfert atmospherique et bilan du Krypton-85, Thesis, University of Paris, 1968.

Telegadas R., and G.J. Ferber, Atmospheric concentrations and inventory of Krypton-85 in 1973, Science, 190, 882-883, 1975. 
Weiss W., A. Sittkus, H. Stockburger, and H. Sartorius, Large-scale atmospheric mixing derived from meridional profiles of Krypton85, J. Geophys. Res., 88, 8574-8578, 1983.

Weiss W., H. Stockburger, H. Sartorius, K. Rozanski, C. Heras and H.G. Östlund, Mesoscale transport of $\mathrm{Kr}-85$ originating from european sources, Nucl. Inst. Meth. Phys. Res., 571574,1986 .

(Received March 6, 1987; revised April 27, 1987; accepted May 6, 1987.) 